\section{André AUBRÉVILLE ${ }^{1}$}

Translation by Ilona BOSSANYI ${ }^{2}$

${ }^{1}$ Inspector-General for Water and Forests in Overseas France

${ }^{2}$ Bois et Forêts des Tropiques

Translation from the original article published in French in the issue $n^{\circ} 33$ of the journal Bois et Forêts des Tropiques, January-February 1954.

\title{
Wild Forests or Silviculture
}

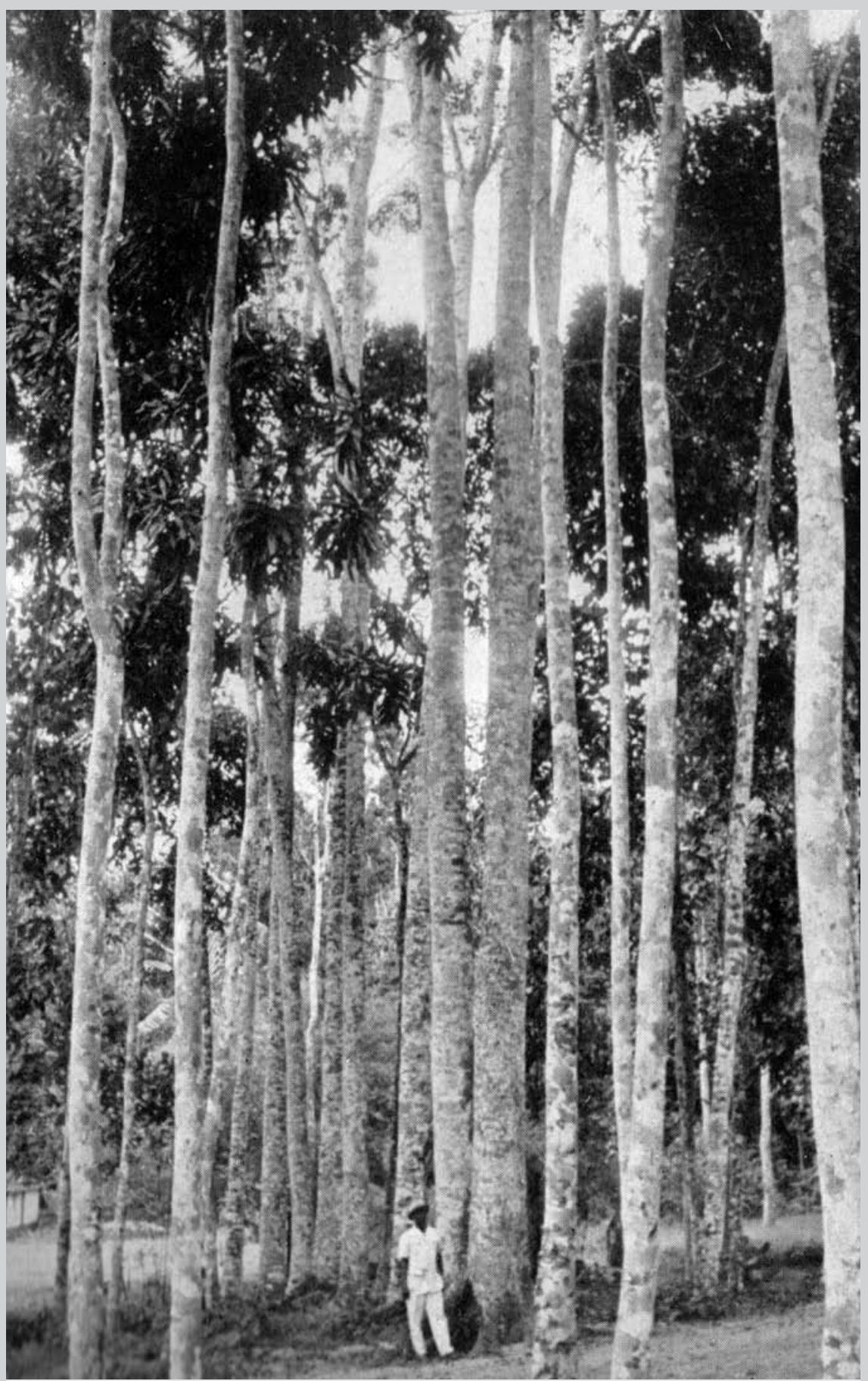

Photo 1.

This fine stand of mahogany grew from seed planted by the author of this article around 1927. The trees are now 26 years old, over $30 \mathrm{~m}$ high with a diameter of $50 \mathrm{~cm}$ at breast height. They were able to develop on very favourable conditions, close to the small Banco River near Abidjan in Côte d'Ivoire. These mahogany trees show what silvicultural methods can achieve in equatorial countries. 


\section{RÉSUMÉ}

\section{FORÊTS SAUVAGES OU SYLVICULTURE}

Dans les pays forestiers du Golfe de Guinée, l'enrichissement des forêts denses, naturellement très pauvres en essences commercialisables, a vu le jour dans les années 1920. Il apparaît en effet indispensable de compenser les pertes de l'exploitation par des opérations sylvicoles qui assureront la reconstitution de la composition primitive en bonnes espèces. Une telle activité, parfois vivement détractée, mais qui convertirait pourtant favorablement des forêts sauvages en forêts valorisables, ne peut être conçue que dans la durée. Cela n'est possible que si les moyens mis à disposition des forestiers sont garantis durablement. L'enrichissement se justifie par le faible nombre d'essences forestières commercialisées, lesquelles demeureront les mêmes dans cinquante ans parce qu'elles disposent des meilleures propriétés technologiques. Une forêt enrichie en okoumés, limbos et niangons, avec une production de 50 à 60 arbres exploitables par hectare, aura donc toujours plus de valeur qu'une forêt sauvage. Cet enrichissement est justifié par la raréfaction progressive des espèces les plus exploitées, inaptes à se renouveler sous un couvert dense. On sait par exemple que les zones riches en okoumés ne le sont que parce qu'elles ont été précédées par l'occupation ancienne de populations humaines qui ont depuis disparu. L'enrichissement se justifie aussi pour éviter que l'exploitation ne se diffuse à l'ensemble des massifs forestiers et entraîne progressivement leur disparition. Les scieries font en effet souvent le vide autour d'elles, et les pistes forestières concourent au mitage des forêts, jusqu'à leur mise en valeur agricole. Sans classement de forêts et sans sylviculture, il n'y aura plus, dans quelques dizaines d'années, ni forêts économiquement exploitable, ni industries forestières en vue du commerce d'exportation.

Résumé adapté par la rédaction de la revue.

Mots-clés : Aucoumea klaineana, enrichissement, forêt tropicale, industrie de transformation, sylviculture, Côte d'Ivoire, Golfe de Guinée.

\section{ABSTRACT}

\section{WILD FORESTS OR SILVICULTURE}

In the forested countries around the Gulf of Guinea, enrichment planting in dense forests with few naturally occurring commercial species began in the 1920s. It is clearly necessary to offset forest losses from logging by conducting silvicultural operations to reconstitute a forest's initial composition using suitable species. Such a strategy, which is sometimes strongly opposed but would convert wild forests into forests with greater potential value, can only be applied with a view to the long term. And this is only possible if the means provided to foresters are guaranteed over the long term. Enrichment planting is justified by the small number of commercial forest species, which will still be the same species in fifty years' time because they have the best technical properties. A forest enriched with okoumé, limbo and niangon to produce 50 or 60 commercially valuable trees per hectare will therefore always have more value than a wild forest. Enrichment is also justified by the increasing rarity of the most sought-after species, which cannot regenerate under dense cover. For example, we know that the abundance of okoumé in certain areas is the result of early human settlements that have since disappeared. Enrichment is also justified as a means of preventing logging from encroaching into the entire forest and gradually destroying it. Sawmills often decimate the forest surrounding them, and forest roads contribute to its fragmentation until cropfields take over the soil entirely. With no listing of protected forests and no silviculture, within just a few decades there would be no more economically viable forestry and no more forest industries manufacturing timber products for export.

Abstract adapted by the editorial team.

Keywords: Aucoumea klaineana, enrichment, tropical forest, manufacturing industry, silviculture, Côte d'Ivoire, Gulf of Guinea.

\section{RESUMEN}

\section{BOSQUES VÍRGENES O SILVICULTURA}

En los países forestales del golfo de Guinea, el enriquecimiento de las selvas, naturalmente escasas en especies comercializables, surgió en la década de 1920. Parece pues imprescindible compensar las pérdidas causadas por la explotación mediante operaciones silvícolas que garanticen la reconstitución de la composición primitiva con las especies adecuadas. Esta actividad, en ocasiones fuertemente criticada, a pesar de lo favorable que sería convertir estos bosques salvajes en bosques aprovechables, sólo puede plantearse como un proyecto de largo recorrido. Esto sólo es posible garantizando de modo duradero los medios puestos a disposición de los dasónomos. El enriquecimiento se justifica por el reducido número de especies forestales comercializadas que, además, seguirán siendo las mismas dentro de cincuenta años porque son las que tienen mejores propiedades tecnológicas. Un bosque enriquecido con okumé, limba y niangón, con una producción de 50 a 60 árboles aprovechables por hectárea, tendrá siempre más valor que un bosque salvaje. Dicho enriquecimiento se justifica por la progresiva rarefacción de las especies más explotadas, inaptas para renovarse bajo cobertura densa. Sabemos, por ejemplo, que las zonas con abundancia de okumés lo son porque fueron precedidas por antiguas ocupaciones humanas que posteriormente desaparecieron. El enriquecimiento también se justifica para evitar que la explotación se extienda al conjunto de las masas forestales y conlleve paulatinamente su desaparición. En efecto, los aserraderos suelen crear espacios vacíos a su alrededor y los caminos forestales contribuyen a la merma de los bosques hasta llegar al desmonte para su desarrollo agrícola. Sin protección de los bosques y sin silvicultura, dentro de unas décadas ya no existirán bosques económicamente aprovechables, ni industrias forestales con miras al comercio de exportación.

Resumen adaptado por la redacción de la revista.

Palabras clave: Aucoumea klaineana, enriquecimiento, selva tropical, industria de transformación, silvicultura, Costa de Marfil, golfo de Guinea. 
Any forestry programme must be designed for the long term. It always takes many years for a young forest tree to ensure its survival. It needs long-term care, failing which it will die of suffocation. Unfortunately, such programmes, precisely because they are designed for the long term, imply equally long-term consent from its promoters and particularly from those who commission and finance the work and from the politicians who hold the purse strings in mainland France. Yet such sustained determination is rarely to be found, if at all, in human efforts. Changing circumstances, fashions, reformers, detractors: people's minds are perpetually changing, sometimes in favour and sometimes not. Whether a forestry programme is opportune will inevitably be questioned sooner or later. Like every long-term human endeavour, it will always be subject to criticism. We must keep robust arguments close to hand, ready to pull out from the files in which they lie, we must ceaselessly strive to persuade thanks to the power of our reasoning and the evidence of hard fact. Success always comes at the end of the road to those who are sure of their arguments and their determination, and provided time is on their side.

It is because our ideas on forest enrichment are presently causing surprise in some quarters, and disenchantment or fatigue in others, that I believe fresh exhortations are needed to move into a new phase, or in other words, to take us up to the next wave of criticism and ensure that those who have followed the right path up to now are not troubled in their conscience.

Dense equatorial forests, or rainforests as they have come to be known, are heterogeneous; with few exceptions, different tree species coexist in colourful company. Within this patchwork, only a few species have attracted commercial interest - no more than thirty species along the entire West African coast have done so. All the others, the many hundreds of "miscellaneous trees", are discarded as having no commercial value. Technical knowledge has in fact confirmed these initial commercial choices almost exactly, occasionally adding a few species to the existing list. It is said that African forests contain few useful species, a fact confirmed by more than 50 years of logging and trade. Hence the call for silviculture, whose tasks appear to lie plainly ahead. From its distant past, the African continent has inherited the wildness of its disordered forests, which it is the task of foresters to domesticate in order to supply the timber needs of our European civilisation. But they must obviously do so with care, because they know that nature cannot be misused. Hence the idea of silvicultural enrichment. Oh, but African foresters are always modest in their ambitions. They would consider themselves fortunate, those of the present generation at least, if, in the places where Africa's age-old nature sparingly offers them one or two usable trees per hectare, they could leave the next generation with 20 or 30 such trees, and more if possible. And more is indeed possible: we can now expect to see 50 to 60 large usable trees per hectare, or 300 to 400 metric tons of high-quality timber. But we also know that we should not tempt the forest spirits to take their revenge by destroying efforts that we have arrogantly ill-conceived. Let us leave the next generation, or the next again, with the task of perfecting the enrichment of the forests they will inherit.
Thus did the first foresters first envision their silvicultural tasks. They sought and experimented with various methods, giving their preference to one or more depending on sites, species and tendencies. All had to fulfil the same condition: their low cost per unit area transformed. It is clear that we cannot spend as much money on trees that must grow for 50 to 80 years before they are felled as on plantations that will yield a profit within just a few years.

I will return later to the results of this early silvicultural work; for now, my immediate concern is to challenge the objections that arise. First, the foundations: are they based on solid ground?

Our detractors are those who do not know, those who doubt, and those who are selfishly indifferent.

I will first address the former. They are in good faith, and perhaps will one day become our most ardent advocates.

Why should we cultivate tropical forests? They are eternal. Does not the logger who, among the larger trees, has felled those - and only those - of interest to those who use them, not leave behind small trees of every type that will spontaneously grow to replace their vanished forebears? Is this not how our forests in France are continuously felled and re-established?

The answer is more complex and more subtle than this simple question. Among the species used, many are known to be light-demanding. Left in the undergrowth of the vast shadowy forest, their descendants can only vegetate and gradually die. This is why there are so few saplings of lightdemanding species and why, when they are found, they are often as sickly as deformed children, too puny for any care to transform them into healthy and vigorous individuals. This is the case with African mahogany, and to a lesser extent with limba, framire, other mahoganies, ilomba, azobé, etc. Thus, when large trees of these light-demanding species are removed, what remains is a feeble, stunted population of descendants with poor chances of survival. Furthermore, the clearings made by felling are soon colonised by seedlings of the species that remain standing, those that cannot be used. In short, as I will not go into all the details that would not change my overall conclusion, this is how a forest from which the best light-demanding trees are extracted will eventually become exhausted. But how, then, can we account for the fact that in a hectare of wild forest, one or two of the fine trees such as those that were felled will still be found? This is an average figure, because in some cases, five or six niangon trees may be found per hectare for example, and 10 to 20 okoumé. Here we must turn to the mysteries of forest regeneration. Not all have been elucidated, and a great deal of observation and patience are required.

When large groups of okoumé and limba, for example, are found in a forest, this is a sign of early occupation by man. Okoumé in particular will only regenerate in open spaces, such as clearings made for crops. The relative abundance of okoumé in some forests in Gabon undoubtedly indicates that they were inhabited in the past by farming populations who later vanished. Two successive conditions had to be fulfilled to create this abundance of exploitable okoumé trees: first, a human community that created a clearing, then that population's disappearance. The same is true for framiré 


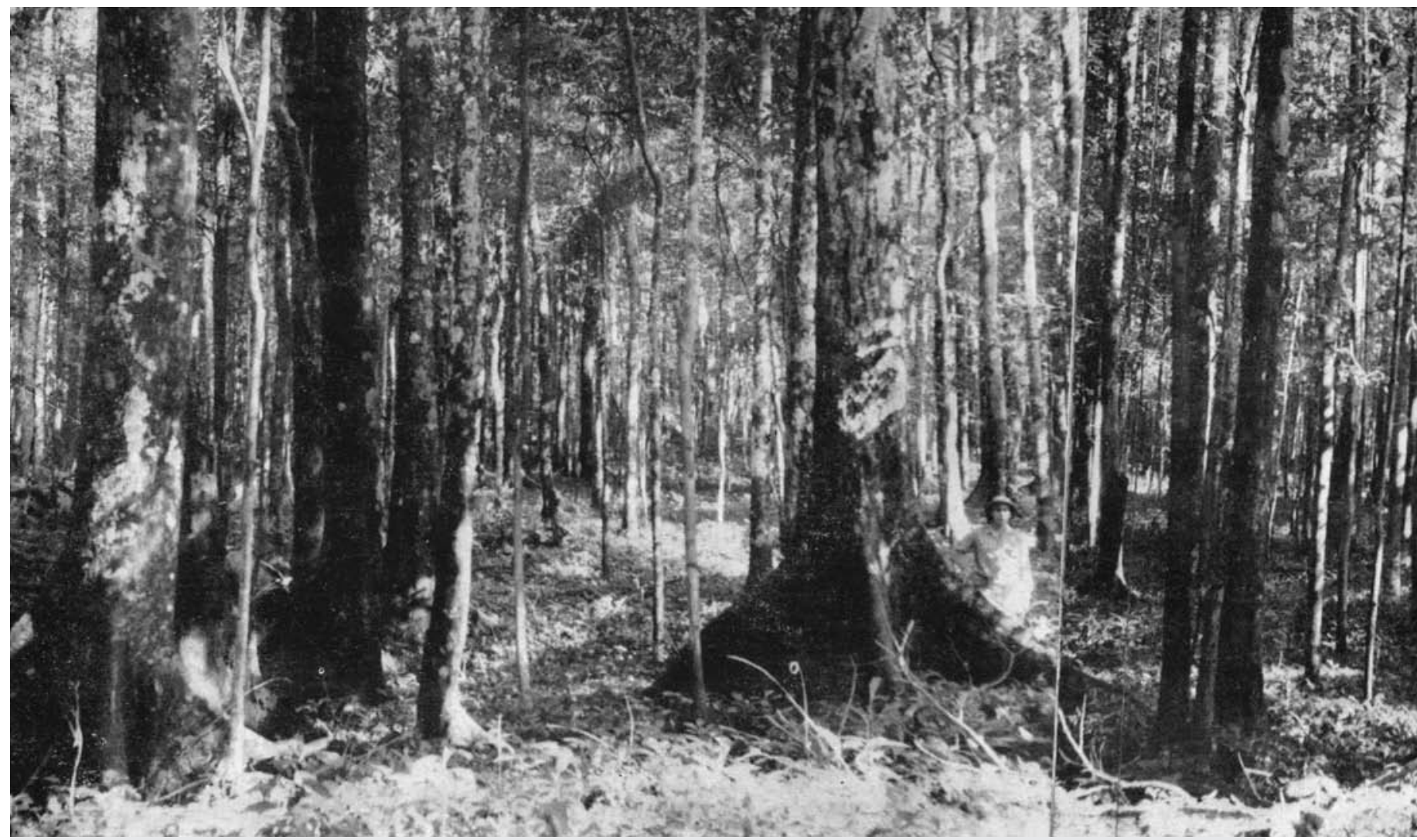

Photo 2.

Apart from the buttress roots of some of the tree, this could almost be a photograph of the Forest of Fontainebleau.

This photograph of a young and almost pure stand of Gaboogives a good idea of the potential wealth of the mahogany forests that could be established in Gabon, replacing wild forests. Photograph taken in the so-called "conservation" parcel in the listed forest of Cape Esterias, November 1953.

Photograph A. Aubréville, 1953.

and ilomba, amongst others. These species only sporadically reproduce in primary forests, in clearings formed accidentally by high winds, for example. Today, such conditions still occur but rarely: cultivation is more intensive, population density is increasing, fallow periods are becoming shorter and fewer large trees are kept in cropfields: in short, the chances of natural repopulation by useful species are lessened.

All these circumstances work against the reconstitution of a forest's initial value in terms of useful species. It is well known that as soon as a logging road is opened up, a patchwork of plantations quickly becomes established along it, while slashing and burning for crops begins to reach into the interior. The edges of untouched forest recede around economic centres and sawmills, so that supplies have to be transported over ever greater distances, with more difficulty and more expense. The sawmills create a vacuum around themselves; they remove the best timber and farmers destroy the rest, including the preexisting natural vegetation on which our hopes for the forest's regeneration might have been founded. In France, forests are permanent and managed to be exploited indefinitely. In Africa, sawmills will one day lack supplies for lack of elementary precautions to protect the forests around them.
If we do not remedy this situation, logging, and the timber industry as a whole, will disappear in Africa. Thus, a paradox looms in the not too distant future: the disappearance of the timber industry in Africa, even as, given the reputation of Equatorial Africa's forests, we should expect it to expand. Large tracts of forest will always remain, of course, but far in the interior, beyond the reach of economically viable transport to export their timber. The vast timber reserves of equatorial forests will have become an illusion, their potential for production and revenue wasted and destroyed.

It is therefore essential to create productive forest preserves in the most easily accessible coastal regions. The operating expenses will need to be offset through silvicultural work to reconstitute, at the very least, the initial composition of the forest in useful species. These objectives have not yet been achieved, however, despite the enrichment programmes conducted with FIDES funding. In Gabon, for example, 300,000 to 350,000 metric tons of okoumé are removed each year. At present, the plantations established by the Forestry Service can only guarantee, once they are mature, 75,000 metric tons of timber production, and only for as long as it receives the credits currently awarded by the FIDES. 


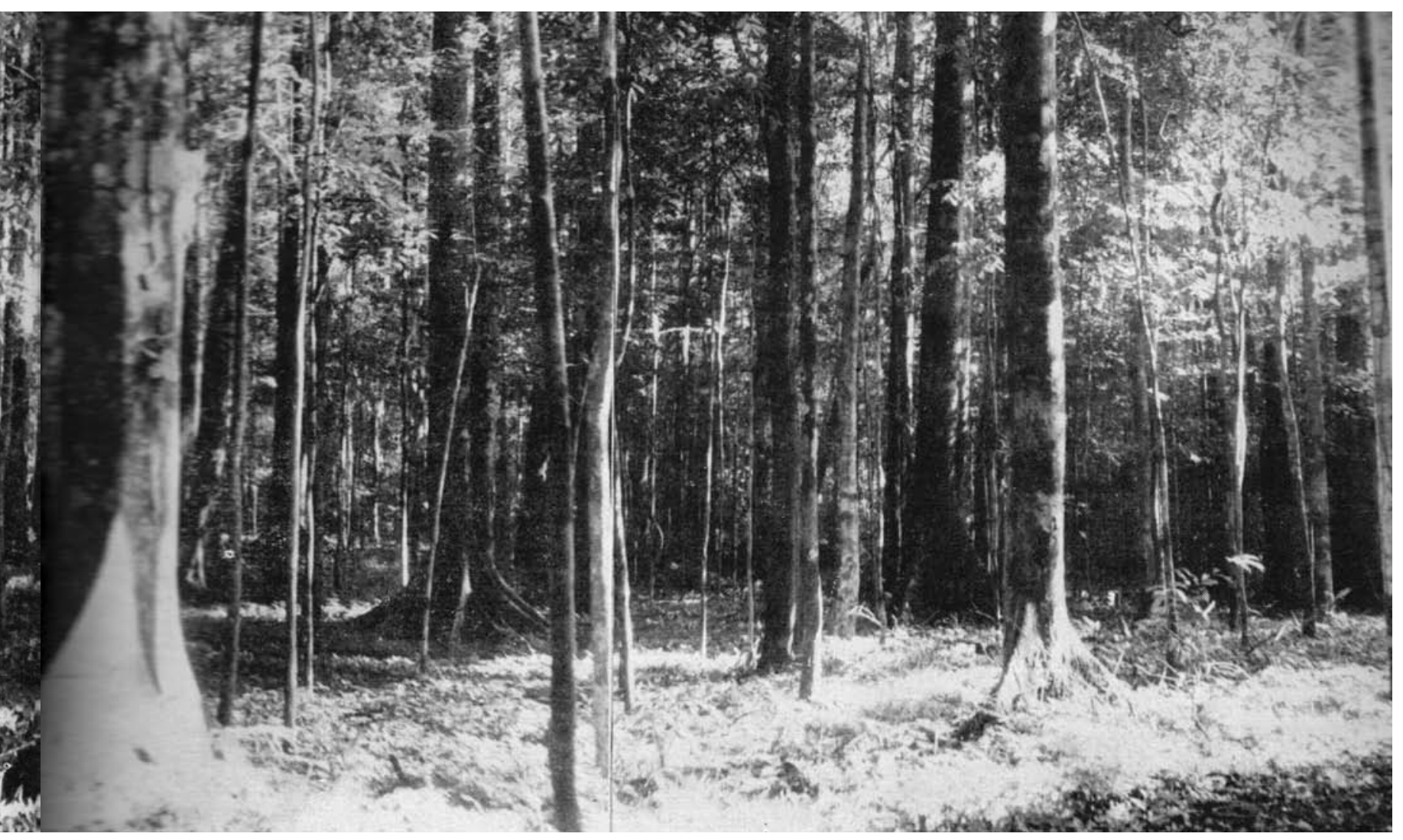

We need to take a hard look at the situation. For 50 years, we have been extracting forest capital on the West Coast of Africa whenever it has been economically viable to do so. This capital is being depleted year by year and is barely being replenished, if at all. The logging front is moving further into the interior and will soon reach the limit beyond which will no longer be economically viable to export the timber. Already, some of the best species are becoming scarce. Fortunately, there are still unexploited forests where logging will become possible as means of transport develop. These are our last reserves, after which only the preserves that foresters have enriched will remain. Today's purely extractive and exploratory logging will inevitably disappear. Loggers will no longer return to previously felled areas because they will have been cleared, or will contain so little usable timber that felling will no longer be viable.

Have I convinced those who did not know and therefore could not see what may lie ahead? I hope so, and I will now turn to those who doubt. They already know, perhaps, but they are sophists and they will be more difficult to persuade. I shall try nevertheless. I believe I can summarise their arguments in three points:

$1^{\circ}$ Among all forest species, we have been able to select the most useful, but will these choices satisfy needs in a hundred years' time? Species we have no use for at present may become those most sought-after, and the future may treat our prized okoumé, mahogany or niangon with scorn. If we bear this possibility in mind, should we really be enriching the forest with these species? Is this not a waste of resources? The better option is surely to fell the trees in today's wild forests, where future generations may find the species they need, rather than persist with ill-judged enrichment that may serve no useful purpose. In short, the enrichment policy is an illusion.

$2^{\circ}$ Mechanical and chemical timber processing industries are making tremendous strides and are increasingly using disorganised woody material with no distinction between different timber species. We are moving towards a time when these industries will be able to use every kind of tropical timber, but when today's foresters carry out enrichment planting, they partly, and sometimes completely, destroy the natural forest by replacing it with a different forest which is more useful to them. But this is surely also a waste of resources and raw materials! Silviculture could actually become uneconomic and the expenditures it requires would be made to no purpose.

$3^{\circ}$ Traditional uses of wood are losing ground every day to competing new materials, such as cement, plastics and metals, which are more convenient to use and more economic. So, why persist with silviculture? We could even let the forests disappear if such is to be their fate. At most, we should preserve it in those places where it is said to have a useful role in protecting soils and water and moderating the climate. We should certainly not be wasting budgets that are ready too limited on conserving exploitable forests, and especially not on silviculture. 


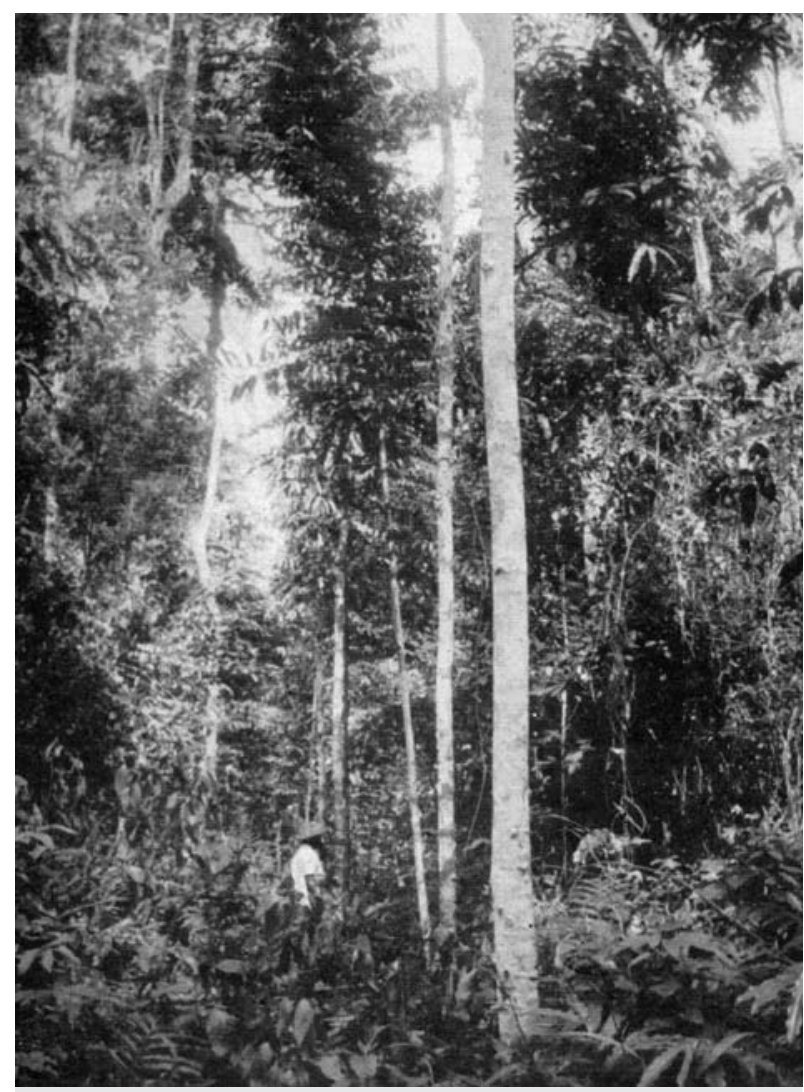

Photo 3.

The strip-planting enrichment technique is ideally suited to mahogany and niangon. This example in the South Yapo Forest in Côte d'Ivoire shows a line of 10-year-old mahogany trees. Photograph Lepitre, 1953.

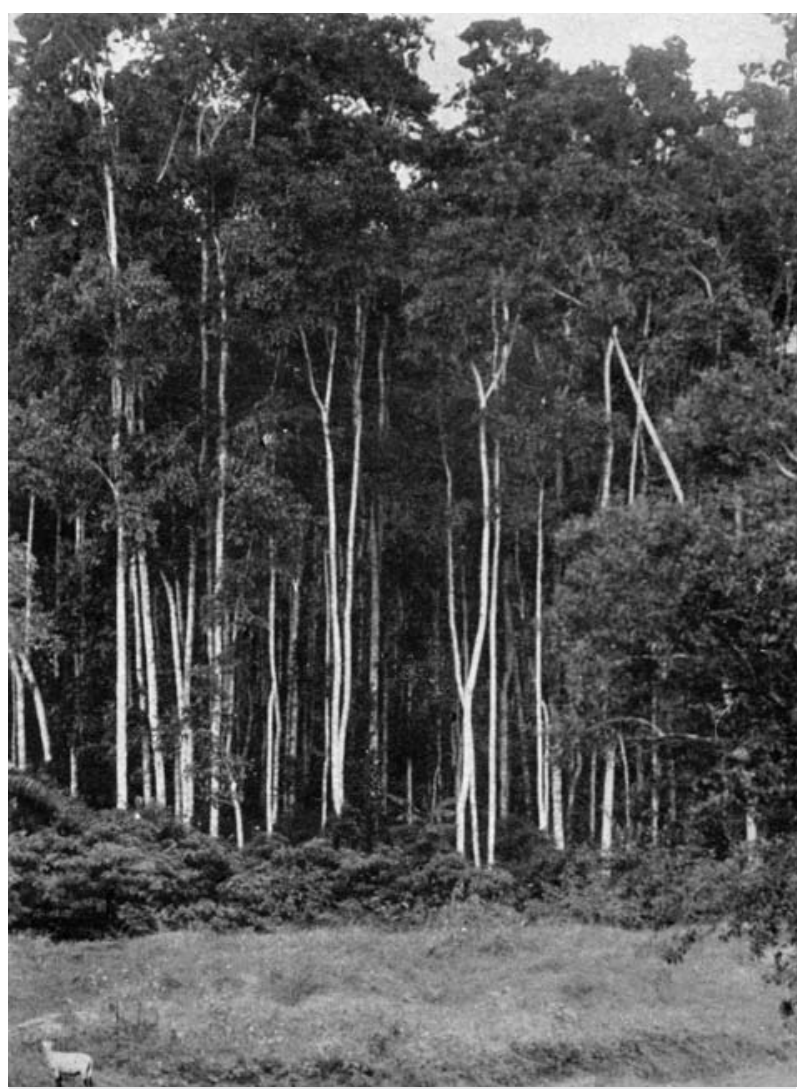

Photo 4 .

Niangon is an admirable species in Côte d'Ivoire, and is now producing highly prized timber. It can be easily multiplied by on-site planting and by natural regeneration. The photograph shows a 1930 plantation of niangon in the listed South Yapo forest in Côte d'Ivoire. Photograph Lepitre, 1953.
In short, let us not worry about the consequences for forests, even if we see they are declining or even dying off. For now, we should put aside our requests for credits from the FIDES and the local assemblies.

100 years is usually the time allotted for a forest plantation to become viable. In France, it takes two centuries to create a high oak stand. In equatorial Africa, we can expect less time. Half a century is probably enough for our softwood species such as okoumé, ilomba, limba or fraké, and 80 years for mahogany and similar timber. It is true that at this age, which is an average human lifespan, we will no longer find the giant trees we are felling today, with diameters of 1.50 to $3 \mathrm{~m}$, but trees 70 to $80 \mathrm{~cm}$ in diameter and 30 to $40 \mathrm{~m}$ high are still fine commercial trees. But can we predict what the use value of different species is likely to be in 50 or 80 years' time?

If we look back half a century, we will see that the choices made in the early 2oth century are exactly the same as today. We were just beginning to discover the African mahogany and okoumé, which are still equally prized and whose depletion we are beginning to deplore. In fact, the choices made were founded on the intrinsic qualities of the timber.
Long before logging by the white man, Africans had already chosen mahogany, okoumé, iroko and others to meet their needs. These are the trees that produce the best timber today, but also for tomorrow, from every point of view. Some uses will disappear, but others will emerge for which the same timber will be used because they have the best physical and mechanical characteristics. Two hundred years ago, the magnificent old oak forests in western France were used to build ships. Their wood has now been replaced by steel for shipbuilding, but with the development of modern sawmills, it has taken on new value. Today, more than ever, the whole of Europe is buying the timber planted for Colbert's navy in the Forest of Tronçais.

Okoumé is the best species for veneer. Because it is also abundant in the forests of Gabon, it has become a source of wealth for equatorial Africa. But okoumé also supplies an excellent material for fibreboard and paper pulp, although it is not used for these purposes because it is too expensive and already in great demand for veneer. It is also well suited to light carpentry. Okoumé timber is soft and resilient and will continue to be appreciated for a wide range of uses, and it is 


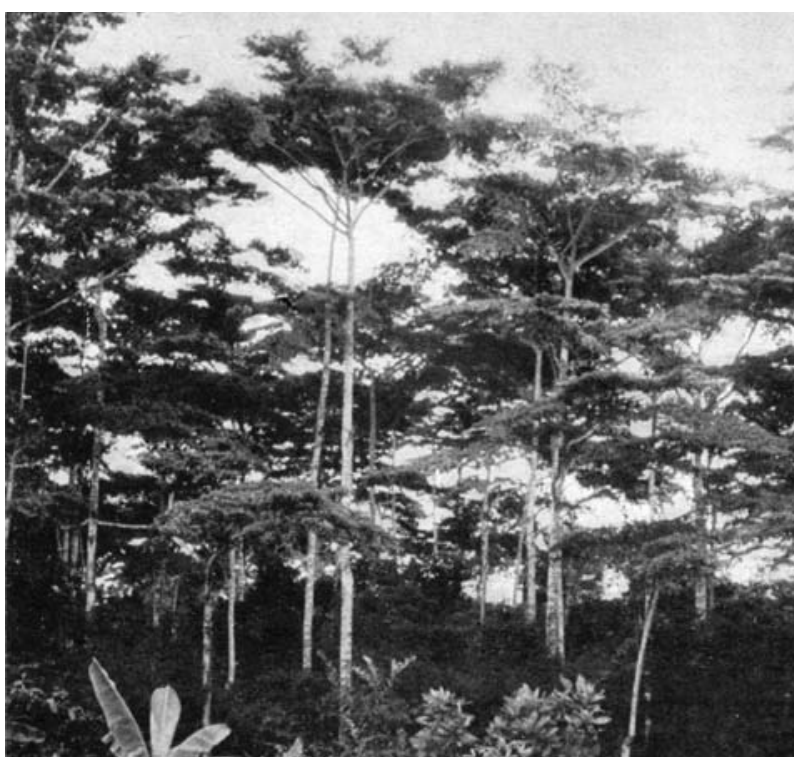

Photo 5.

Establishing forest plantations in sites initially cleared for subsistence crops can produce better results in terms of tree growth when softwood species are used. Here, a plantation of framiré on land that was cleared for crops in 1936, in the Abobo Forest near Abidjan in Côte d'Ivoire.

Photograph Lepitre, 1953.

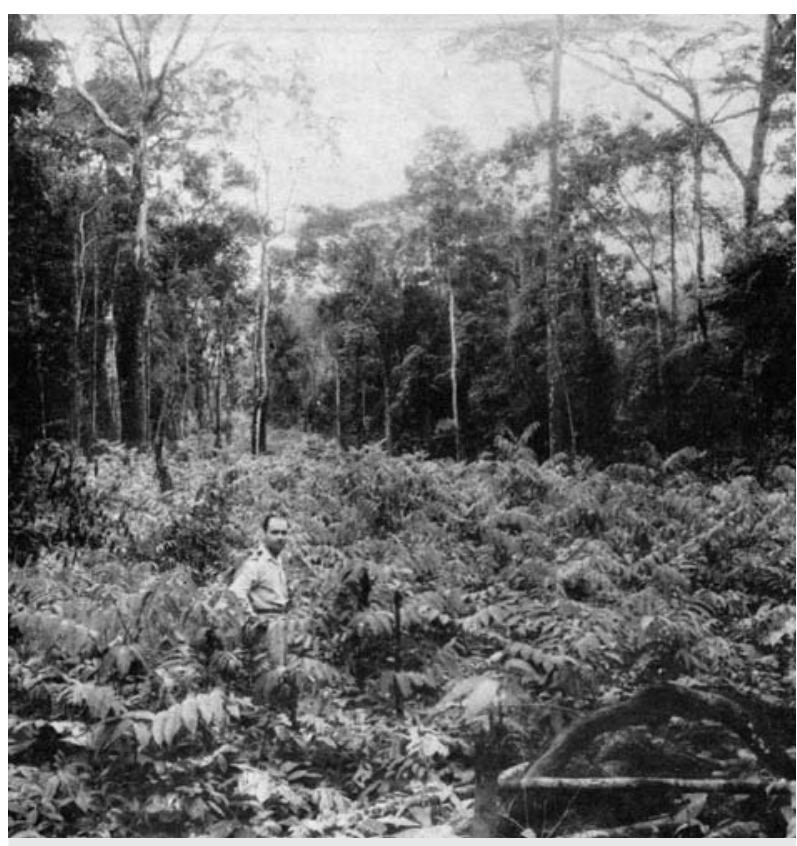

Photo 6.

A forest trail becoming overgrown by naturally regenerating one-year-old okoumé trees.

Cape Esterias listed forest, Gabon. November 1953.

Photograph A. Aubréville, 1953. easy to grow in Gabon. Under good soil and maintenance conditions, okoumé plantations can be exploited after 50 years. Better then to accept the risk involved in silvicultural management than to have to take responsibility for refusing to create a source of wealth in Africa's forests, and to take advantage of the existing situation where logging can prosper.

As long as wood continues to be used as a material, the preference will be for mahogany, niangon, cherry mahogany, etc., because of their quality. The only reason why they are not more widely used at present is simply that their rarity in our African forests makes the cost of production relatively high. They will never be surpassed by any other African species. The choice is a good one. New species may appear on the market but they are not better. They are accepted as substitutes because the older species are no longer abundant.

Technical progress in the mechanical and chemical timber industries is indisputable, and brings new hope for the future of our tropical forests. The most encouraging recent demonstration is the example of the Colonial Cellulose Industrial Board (Régie industrielle de la cellulose coloniale), whose paper mill in Côte d'lvoire is manufacturing paper commercially from a mixture of hard and soft wood from the surrounding heterogeneous forest. There is hope today that it will become possible to use a wide range of tropical timber to manufacture cellulose pulp, fibreboard and perhaps, in the future, crystallised glucose, yeasts for the food industry, furfural, fuel, fertilisers and so on. Possibilities for wood distilling and especially hydrolysis were the subject of an article

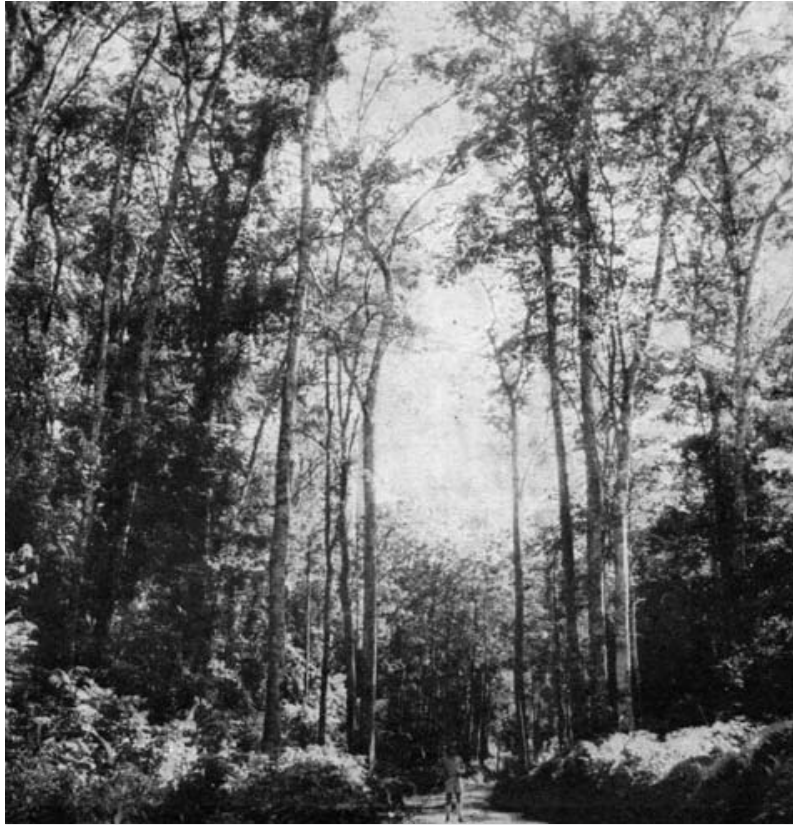

Photo 7.

A young natural stand of Okoumé along the Libreville to Cape Esterias road: note the slenderness of the trees. November 1953.

Photograph A. Aubréville, 1953. 


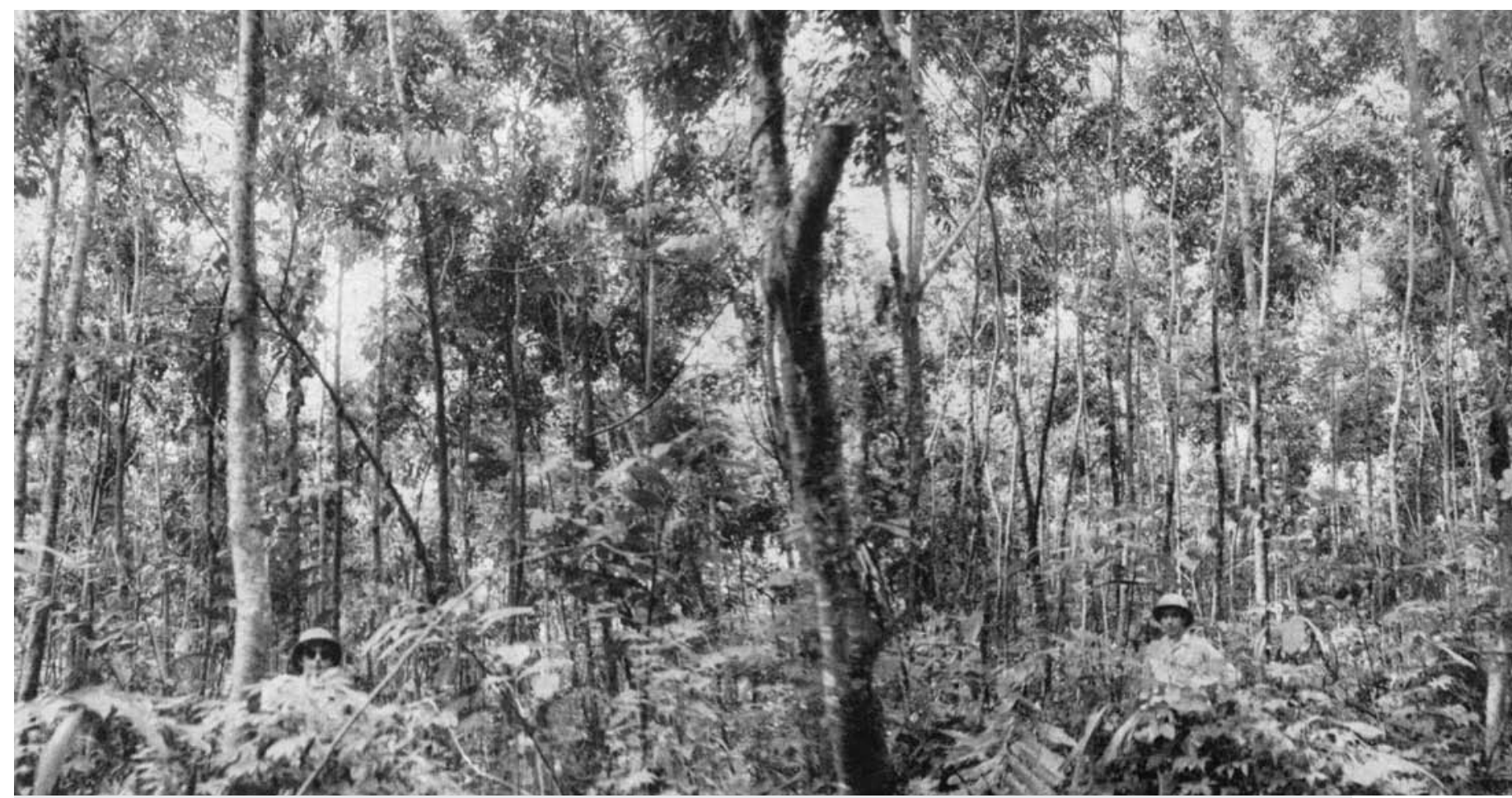

Photo 8.

View of an okoumé plantation established in 1947. After thinning, the young six-year-old trees are still numerous. Note the light ground cover provided by the stand. Cape Esterias listed forest, Gabon. November 1953.

Photograph A. Aubréville, 1953.

I published in the "Revue des Eaux et Forêts" [Water and Forestry Journal] in 1939, entitled "L'utilisation totale des bois tropicaux dans l'Ouest africain" [Total use of tropical timber in West Africa]. I still have great confidence in the possibilities for chemical treatment of wood materials, regardless of species, although my enthusiasm is now based on more solid ground thanks to the experience acquired with tropical timber in this area since before the war. As regards cellulose pulp for example, many kinds of tropical timber cannot be used in combination, for technological reasons (almost impossible to cut or badly deformed trunks), for chemical reasons (Ebenaceae) or because the paper produced is too poor in quality. As regards hydrolysis of tropical timber, the studies by Professor Savard have shown that certain hydrolysis fluids are not fermentable. Hydrolysing wood mixtures would be very difficult, as different types of wood do not react in the same way. But yields are perhaps, and especially, the main problem; they are high with certain types of wood and average, mediocre or decidedly poor with others. For all chemical timber industries, if only from the profitability angle, the question of selection and elimination therefore arises. A machine that could handle every kind of wood without previous sorting has not yet been invented. The Lacotte gasifier is perhaps the only existing type of apparatus capable of indiscriminately consuming any kind of wood, but using it in the tropics is still problematical. The synthetic fuel it would produce does not seem likely to become widely used at a time when petroleum indisputably reigns supreme.

These industries of tomorrow, therefore, are raising our hopes of using more tropical species, but not all, either for technical reasons or because yields are insufficient. Furthermore, it will always be preferable, for an industry, to exploit relatively homogeneous forests comprising selected species, rather than the wild multi-species forests we have at present. The reason why we use the latter, as they stand and despite the many disadvantages, is that they are all we have: we have to try to use the raw material that exists as long as we can calculate that the disadvantages will be compensated by its low cost. Even for the industries of tomorrow, it is likely that forests with an abundance of okoumé, limba, niangon, etc. will be more valuable than wild forests. Okoumé is an excellent species for paper pulp, niangon is also among the very best we have found in Côte d'Ivoire, and the same goes for limba in the Congo. Can it be coincidence that these fine species are the most sought-after for paper manufacture?

We come now to the third type of argument. Will we still be using wood a hundred years from now? The same question could have been asked a century ago, yet the tropical species known at the time -mahogany, teak, rosewood, ebony - are still as prized as ever, despite changing fashions in furniture as tastes change from dark to light wood and back. It is true that some uses of wood are declining, as other materials compete for its many uses. But wood is holding its own. We are finding new ways of using wood that overcome some 


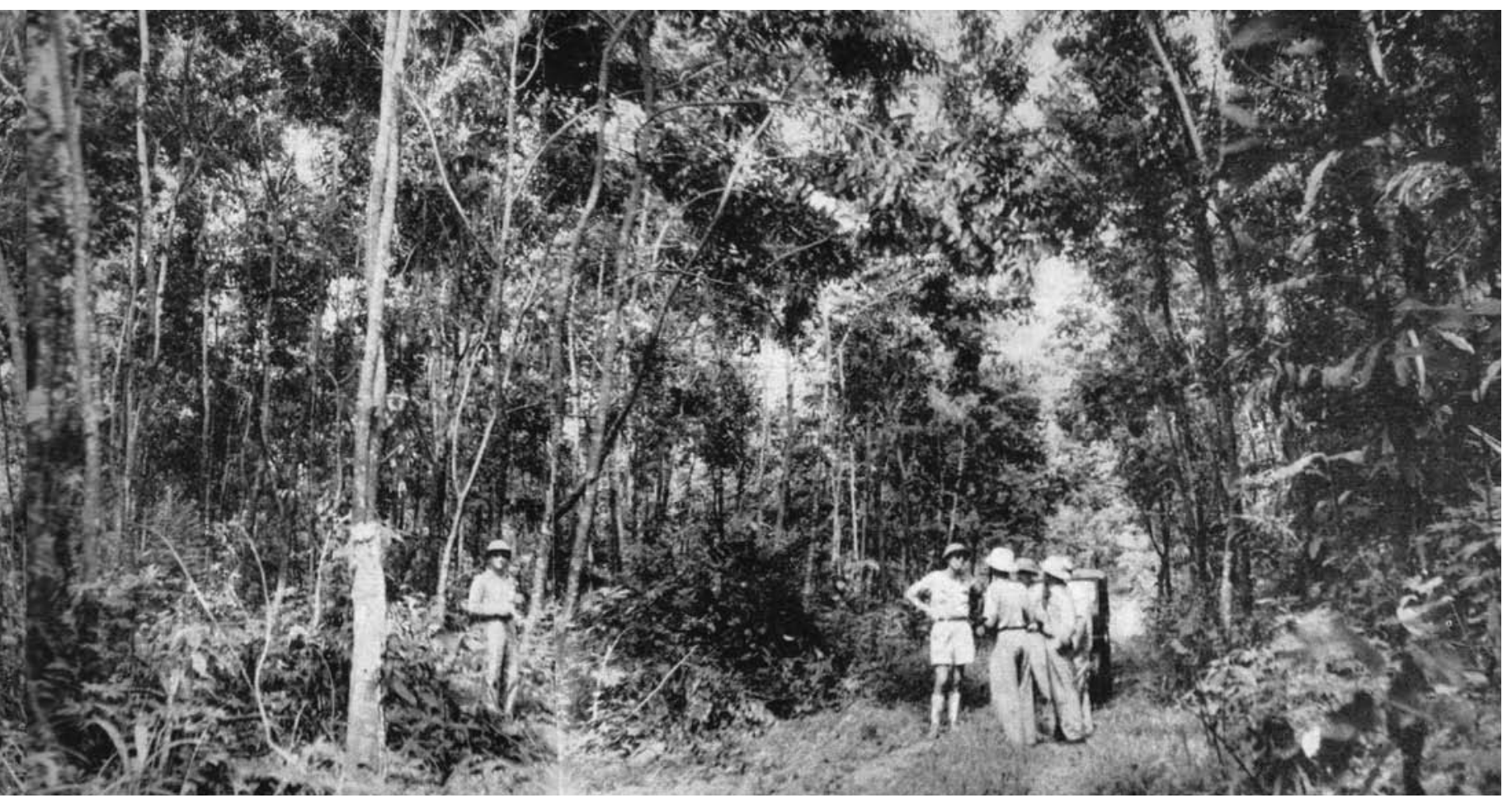

of its disadvantages: plywood, veneers and boards of every kind. Paper consumption is steadily increasing, and even traditional uses of wood are still in favour. Metal furniture is soon outmoded, easily damaged, disagreeable to the touch and hard to repair, and unlikely to dethrone its counterparts made from wood. Wooden houses are still widespread in industrialised countries, such as the United States, which have abundant materials of every type, while in Africa, those who live in concrete houses where every passing truck makes it impossible to hear oneself speak may well regret that in these poor countries, for lack resources and finance, we have given priority to cement over wood. But let us not take these considerations too far: if we continue to follow those who prophesy the demise of wood as a material in the next 50 or 100 years and who would abandon our wild forests to their fate as a result, we may well incur the reproaches of future generations who, very probably, will still need wood and will go to find it in those countries that have created reserves.

No, the decline of wood is not upon us. If we refer to a very recent report from the second joint meeting of the EEC timber committee and the FAO's European forests commission, held in Rome from 8 to 12 October 1953, we will see that European consumption of high-quality and industrial timber is tending to rise, that we need to increase timber production, to augment national afforestation programmes and improve forest management to ensure that we are better able to satisfy increased demand in the long term, and that governments must ensure that their forests receive the benefit of intensive silviculture by maintaining forestry personnel and the necessary budgets. Such is the opinion expressed recently by European timber economics specialists, who have studied its trends and prospects. Current European programmes provide for 20 years of reforestation and enrichment planting over a total of $16,044,915$ hectares. Our programmes in Africa, and especially the credits that determine their implementation, are small indeed compared to others. The risk involved in undertaking semi-intensive silviculture over a few thousand hectares each year is non-existent. There is nothing forcing us to slow down the efforts we have begun, quite the contrary.

The third group of detractors are of much greater concern than the other two because they deny nothing, neither the truth of our ideas, nor the usefulness of silvicultural programmes, but prefer to merely acknowledge the principle without putting it into practice. They maintain that the amount of investment capital available in African territories is unfortunately too low given the scale of the infrastructure to be developed in every economic and social field - which is all too true. But they add that under these conditions, any available capital should be reserved for the most urgent operations, which can be undertaken now for immediate gain - bridges, roads, railways, electrification, etc. - rather than spent, if only in part, on silvicultural operations that will only become profitable in the long term.

This is a highly dangerous argument because it rests on the selfishness of one generation and because such appeals are readily heard. I have shown that logging practice today, like clearing dense forest for crops, is consuming the natural capital that is nature's legacy. If we do not apply policies for forest protection and reconstitution, this capital will soon be lost forever. Without forest protection and without silvi-culture, within a few decades there will be no more economically exploitable forests and no more forest industries to export their timber. It is not right that today's 
generationshould squanderallthiscapital foritsowngain, thus ruining the prospects of generations to come. In all decency, we should at a minimum replant as many trees as we have felled. As I have already said, we are a long way from doing so. It is of course tempting to consider as a fact of life that today's forests will become exhausted and to reserve all our financial resources, including those produced by the selfsame forests, for operations that provide immediate gain. Fortunately, this egocentric idea is not generally accepted in our territories, or by the Ministry for Overseas France, or by the FIDES steering committee, but still lurks below the surface, as menacing as a conger eel.

It was to protect our forestry programmes from possible cutbacks that we established a forestry fund for Overseas France that would be financed in part by current forest revenues. This fund is essential to ensure the continuity of forestry activities. The local assemblies must take part in their management to be sure that the money is spent in the interests of each territory. It is now a matter of urgency to protect the credits earmarked for forests from selfish appetites.

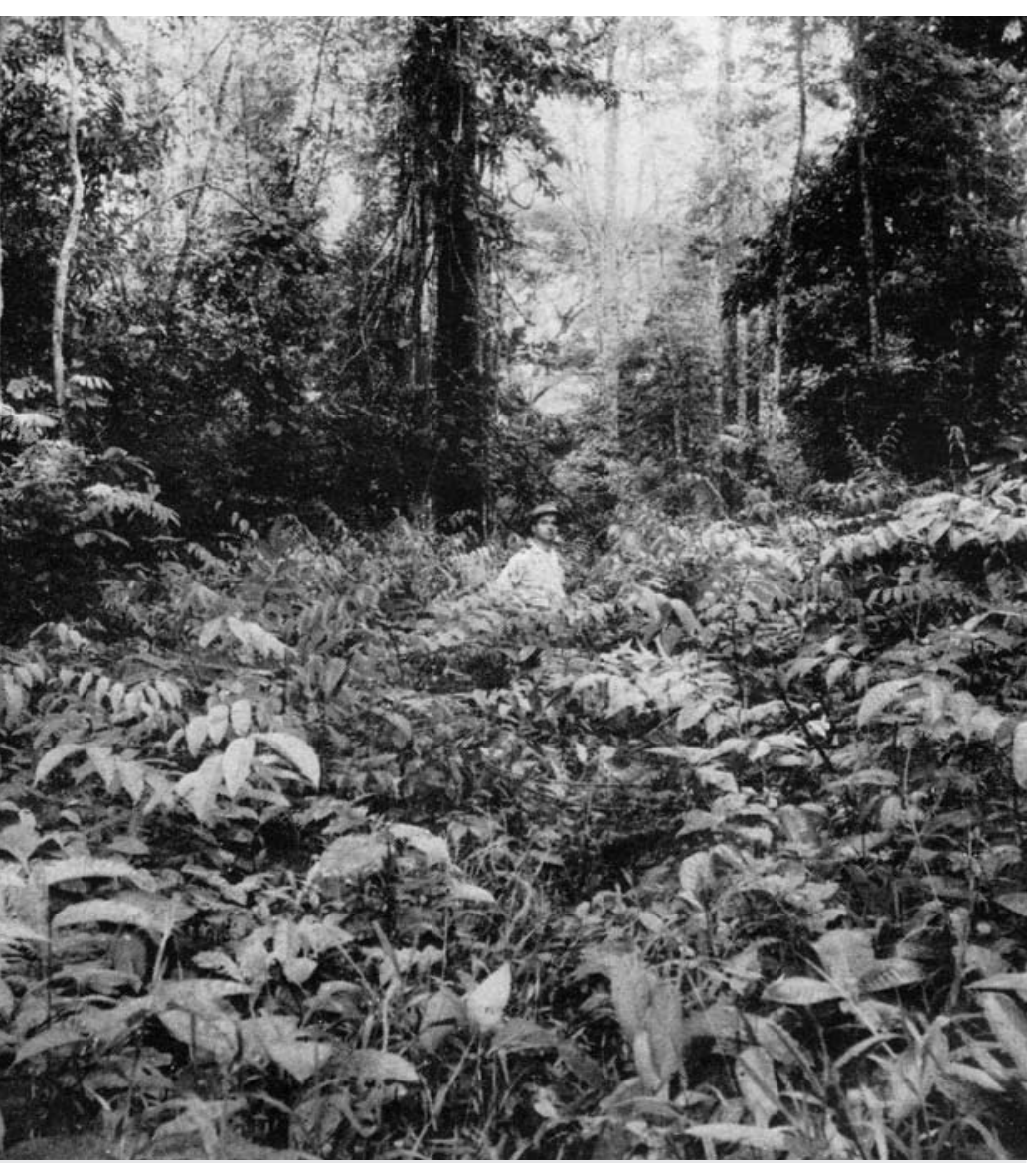

Photo 9.

An okoumé plantation established in 1932

The young trees are growing densely and vigorously in a $30 \mathrm{~m}$ strip opened up into the forest. Listed Forest of Cape Esterias, Gabon. November 1953.

Photograph A. Aubréville, 1953.
Some doubts may yet remain over the possibilities for transforming wild forests through the inevitably rudimentary silviculture now applied from Côte d'Ivoire to the Congo. I have already published notes and figures in this Journal on how the first plantations in Côte d'Ivoire and the Congo have evolved, and do not think I need to return to this subject here. The photographs in these pages show more clearly than any report what has been achieved so far, and also what we can hope for based on observations of natural stands. Silvicultural techniques can still be improved and perseverance is essential. I will nevertheless report some significant figures obtained during my recent tour in Gabon. Felling had just taken place in one of the early okoumé plantations established in Cape Esterias forest near Libreville, in 1944. After thinning and removing badly formed, forked or suppressed trees, 82 trees remained on the 0.25 ha. surveyed, or 328 per hectare, which is a significant number. The dominant trees averaged $26 \mathrm{~m}$ in height and 22 centimetres in diameter; the best tree was $33 \mathrm{~m}$ high and $39 \mathrm{~cm}$ in diameter. This is surely more than encouraging for young nine-year-old okoumé trees.

Our defence of the silvicultural methods applied by our forestry services in Africa also has another purpose. Reconstituting a forest to improve logging efficiency, thanks to the greater concentration of future usable timber, is essential on the African coast, but it is possible to take the matter further. As I have already had occasion to report, equatorial Africa's warm, humid climate is naturally favourable to the production of timber and all cellulose-based products. Its forests cover vast areas whose value will never be fully realised by permanent crops, given the sparse population and the limited market for agricultural exports from the tropics. However, in zones that are served by harbours, forests that can be usefully exploited can fall victim to clearing, while silviculture could transform the most accessible stands into improved forests that would become a significant source of wealth in just half a century.

The same problems arise in all tropical countries across the world, in a similar context of indifference and incomprehension as regards forestry matters. Those who overcome this selfish indifference and who, alone or ahead of others, succeed in creating wealth from forests thanks to protection and silviculture, will become leaders in the international timber trade. There is no great risk in adopting policies to create future wealth from forests, only great chances of success. So why not apply such a policy, using the financial resources available to the limit! Enough wild forests will always remain, far in the interior from the Atlantic Ocean to the furthest reaches of the Congo basin, but we must look to silviculture to transform vast tracts in the middle and lower reaches of the forest basins that contain the fine species we ready know.

Long life and honour to tropical silviculture! 